\title{
Management and Business Ethics in Central and Eastern Europe: Introduction to Special Issue
}

\author{
Anna Soulsby ${ }^{1} \cdot$ Anna Remišová $^{2} \cdot$ Thomas Steger $^{3}$
}

Received: 11 June 2021 / Accepted: 20 August 2021 / Published online: 4 September 2021

(c) The Author(s) 2021

\begin{abstract}
This special issue focuses on the developments in ethical standards in the post-communist countries of Central and Eastern Europe (CEE) including the former Soviet Union. Over thirty years have elapsed since the demise of the Soviet Bloc and, despite some common institutional features, the societies have had very different experiences with uneven developments across the region since the collapse of communism. In this special issue, the authors explore business and management ethics situated within the context of the challenges that face these still transforming post-communist societies. The papers cover a range of issues and countries including Albania, Belarus, Bulgaria, Croatia, the Czech Republic, Estonia, Hungary, Kyrgyzstan, Latvia, Lithuania, North Macedonia, Poland, Romania, Russia, Slovakia, Slovenia. Potential further avenues for research are identified in the field of business ethics in post-communist societies.
\end{abstract}

Keywords Central and Eastern Europe $\cdot$ Communism and post-communist transformation $\cdot$ Management and business ethics · Soviet Bloc

\section{Introduction}

This special issue, which follows on from the last special issue of the Journal of Business Ethics on post-communist societies (Brown et al., 2003), focuses on the developments in ethical standards in the post-communist countries of Central and Eastern Europe (CEE) including the former Soviet Union. Over thirty years have elapsed since the demise of the Soviet Bloc, and despite some common institutional features, the societies have had very different experiences (Hardy, 2014; Myant \& Drahokoupil, 2010, 2012) with uneven developments across the region since the collapse of communism. In this special issue the authors explore

Anna Soulsby

anna.soulsby@nottingham.ac.uk

Anna Remišová

anna.remisova@fm.uniba.sk

Thomas Steger

thomas.steger@wiwi.uni-regensburg.de

1 Nottingham University Business School, University of Nottingham, Nottingham, UK

2 Comenius University, Bratislava, Slovakia

3 University of Regensburg, Regensburg, Germany business and management ethics situated within the context of the challenges that face these still transforming postcommunist societies.

The post-communist societies of Central and Eastern Europe and the former Soviet Union have experienced radical changes since the collapse of communism. The events stimulated enormous interest in how, and how far, after decades of state socialism, these societies could adjust to the globalised economic context. The starting point of postcommunism with the legacy of its inherited institutions, was so distinctive from existing varieties of capitalism that Western social scientists regarded the CEE region as an "immense social laboratory" for the study of radical change at all levels of society (Whitley \& Czaban, 1998, p. 260).

Initially, neo-liberal economists also found a lot of support regionally and internationally for their advocacy of an economic transition defined by the quick introduction of free market conditions and institutions (the so-called 'shock therapy') coupled with the simultaneous eradication of those structures inherited from state socialism (cf. Hoen, 1996). This approach was also politically regarded at the time as a way of preventing the nomenklatura potentially taking back 
control. ${ }^{1}$ The quick introduction of a market economy was seen as a vital part of the process of restoring democracy (Brom \& Orenstein, 1994; Holy, 1996; Kopeček, 2011). Underlying the dynamics of the political and economic shifts in the former state socialist societies of Central and Eastern Europe were fundamental processes of social reformation. It had been argued (e.g., Haynes, 1992) that the pressures for political change for the most part originated from two levels: The grass roots and the top of society. In many of the communist regimes the pressures for change had been resisted, through force, if necessary. The critical element in tipping the balance leading up to the revolutions in 1989 was the reorientation of the interests of the top members. This has had paradoxical effects on the post-communist societal transformation. It is irrefutable that the changes in the political and economic systems of these countries have been revolutionary, a characteristic that has attracted so much Western interest in the problems and destinies of these countries. However, other researchers who have considered the political and economic decision-making behind the changes have tended to suggest that the transition had been directed and driven by the same people as had defended the politico-economic status quo before 1989 (Callinicos, 1991; Haynes, 1992; Wolchik, 1991).

However, in retrospect, it has become evident that the mainstream, western inspired, neo-liberal economic theories preferred by international economic institutions (e.g., the International Monetary Fund, the World Bank, the European Bank for Reconstruction and Development) that had given financial assistance to the region and that guided the reform process at its earliest stages (e.g. Amsden et al., 1994; Lipton \& Sachs, 1990; Sachs, 1996; Whitley \& Czaban, 1998) have failed to account for the deep pull of diverse institutional histories across the countries of CEE, rendering socio-economic shifts towards capitalism both uneven and fragmented (Hardy, 2014; Soulsby \& Clark, 2007).

At a societal level, a particular issue for these former communist societies has been the necessity for the development of new political and economic institutions to meet the requirements of modern European-style market democracies. In CEE, an important part of this process was the move to develop these societies to conform to the norms of the European Union. There have been considerable changes in the region since the fall of communism including the wars in the Balkans and Ukraine and the accession of countries to the

\footnotetext{
1 The key institution responsible for developing and sustaining the previous social elite, or ruling class, was the nomenklatura system. This was a list of posts where the approval of the Communist Party was required for someone hold that position e.g., state enterprise managers or positions in various institutions. This control meant that the Communist Party, at central, regional, and local levels, had maintained a senior group of trusted comrades (Ionescu, 1967).
}

European Union (Czech Republic, Estonia, Hungary, Latvia, Lithuania, Poland, Slovakia, Slovenia in 2004; Bulgaria and Romania, 2007; Croatia in 2013. The other countries of the Western Balkans are in the process of joining the European Union). In addition, the effects of the financial crisis in 2008 are also still being differently felt across the region (Soulsby et al., 2017).

The experience of these radical societal changes, together with the revelations of political and economic corruption, has revealed the need for greater ethical awareness and stronger ethical standards in business and management as the effects and consequences of decisions taken during the early years and middle years of transformation become more apparent (Sicakova-Beblava \& Beblavy, 2016). The ethical problems and challenges that had been created by these radical changes had been recognised early on in the transition. Bohatá, in her research in the mid-1990s, found that there were no governmental initiatives in CEE to tackle problems in the field of business ethics (Bohatá, 1997, p. 1575).

As Remišová et al. (2019) found in their research in Slovakia, in the 1990s, the implementation of business ethics was mostly associated with, or sometimes confused with, the adoption of a code of ethics. The term 'ethics program' was used arbitrarily and was not associated with a systematic or long-term development of business ethics in organizations. In the mid-1990s, the first connections between both Slovak business practice and academia with business ethics were developed. However, at the end of the 1990s there was a change in attitudes to the regulation of business activities in Slovakia. Some businesses with a strong drive for longterm economic success realised that their economic strategy could not be successfully applied in an unethical business environment. The development of appropriate legislative and political structures and an ethical framework with systematic support from the government was needed. Private companies and other not-profit organizations, together with academics, took the initiative and started to develop the theory and practice of business ethics (Remišová et al., 2019). In the field of public administration and local government there have been relatively few studies of ethics and ethical behaviour by public servants (for exceptions, see Bohatá et al., 2018; Kooskora \& Virjoka, 2015; Rybnikova \& Toleikienè, 2019; Stare \& Klun, 2016). It has taken considerable time for ethics to become more important in the field of public administration. This has also had an effect in contributing to a weak political environment in terms of preventing or restraining unprofessional practices and unethical behaviour.

In the early days of the transition period managers of organizations had to respond to the fast changes in their markets and the privatisation of former state-owned enterprises (Filatotchev et al., 1994; Gray, 1996). Managers also had to respond to the challenge of the re-legitimisation of management as an activity in post-communist society where 
managers were viewed as part of the previous repressive state bureaucracy (Bohatá, 1997). They had to demonstrate they had the credentials and expertise to manage organizations along more recognisably western lines and that they could compete with the market challenges posed by arrival of foreign direct investment and new businesses (Clark \& Soulsby, 2007). However, the managers were used to running state-owned enterprises under the system of central planning. The state-owned enterprise was integrated around a simple functional hierarchy, which administered production processes to meet given targets and supply products and services to 'partner' enterprises. These bureaucratic structures, the ideological attachment of senior managers to the Communist Party via the nomenklatura system of political appointment and associated incentive structures strongly encouraged inertia and compliance (Clark \& Soulsby, 1995; Kozminski, 1995). The ideological emphasis of the socialist state on employment as well as the problems created by a shortage economy had also led to senior managers indulging the work force and the systematic creation of overstaffing (Kornai, 1980). Moreover, senior managers usually had little direct experience of markets (unless they worked for the export organizations) and minimal modern technical know-how of systems such as quality assurance. Strategic managers poorly understood the nature of operating in competitive business environments (Myant, 1993; Newman, 2000; Soulsby \& Clark, 1996) and the personnel function was tainted and defined by its relationship to the Communist Party (Koubek \& Brewster, 1995). However, the managers had the advantages of being well-placed in terms of networks and knowledge about the enterprises.

The intention behind the privatisation processes was to create owners for former state-owned enterprises (SOEs), imposing the discipline of the market on decision-making and organizational restructuring. However, the existing management often continued to exercise high levels of discretion over strategic decision-making with ethical consequences for the future ownership and governance of SOEs (e.g., Sanders, 2006). Moreover, the rolling back of the state as part of the neo-liberal approach that was fashionable in the early 1990s meant that the state was often in too weak a position to control the cronyism and corruption that was often part of the privatisation of state-owned assets (Smallbone \& Welter, 2001). Managers were therefore either in position to directly acquire the enterprise's assets or were kept on in their positions by other external shareholders (Hingorani et al., 1997; Reed, 1995).

In reflecting on the radical changes that have happened over the region since the collapse of communism it is timely and important to evaluate these processes of change. Many of the members of the elite that had previously controlled these societies had found a way to survive the transition period. From the early 1990 s, managers that were able to demonstrate competent professional, organizational, functional and technical skills and were adaptable to the new environment were able to survive the period (Steger \& Lang, 2003). Other managers survived through mobilising their social and political connections and networks, maintaining and transforming their communist privileges as former members of the nomenklatura (Clark \& Soulsby, 1999; Ionescu, 1967; Lane, 1976; Soulsby \& Clark, 1996; Večerník, 1999; Waller, 1993). For many, a key attribute was the ability to let go of the past and orient themselves to the requirements of the new market economies (Steger \& Lang, 2003). Also, since the collapse of the Soviet Bloc, a new generation of managers has developed. Since the start of the 2000s, the managers that have survived the political and economic turbulence of the changes of the 1990s, together with the new generation of owners and managers of new businesses that have since been established, have now become members of an elite in a western-marketised society with all the attendant social and economic advantages for them and their families (Hraba et al., 2000; Večerník, 1999).

As discussed above, the rapid collapse of state socialism after 1989 together with the need to cope with the radical changes necessary to create a market economy raised many ethical challenges for business and management. In order to provide a wide perspective in evaluating the changes since 1989 , in the call for papers, the guest editors encouraged the submission of papers from across a range of disciplinary and methodological approaches on the ethical challenges facing business and management, e.g.: The effects of foreign direct investment; developing national government and local civic structures; developing regulatory bodies; developing professional associations; the development of management education in universities. After the call for papers closed, thirtyone papers were received for consideration for the special issue and fifteen papers were sent out for peer-review. After the rounds of review were completed, six papers were finally accepted. The accepted papers (some of which are comparative) cover a range of issues and countries: Albania, Belarus, Bulgaria, Croatia, the Czech Republic, Estonia, Hungary, Kyrgyzstan, Latvia, Lithuania, North Macedonia, Poland, Romania, Russia, Slovakia, Slovenia. Table 1 gives more details and summarises the approaches taken by the authors.

The article by Chadee et al. (2021) is a comparative paper that investigates the influence of formal and informal institutions on firm innovation in transitional economies of Central and Eastern Europe. The authors differentiate between corruption and bribery as distinct informal institutions. They integrate institutional theory and legitimacy theory to explain that the failure of formal institutions creates an environment of corruption which therefore encourages firms to use bribes to facilitate economic exchange. Chadee et al. (2021) use a large sample $(n=1603)$ to test their hypotheses on the innovation performance of firms in eleven countries 


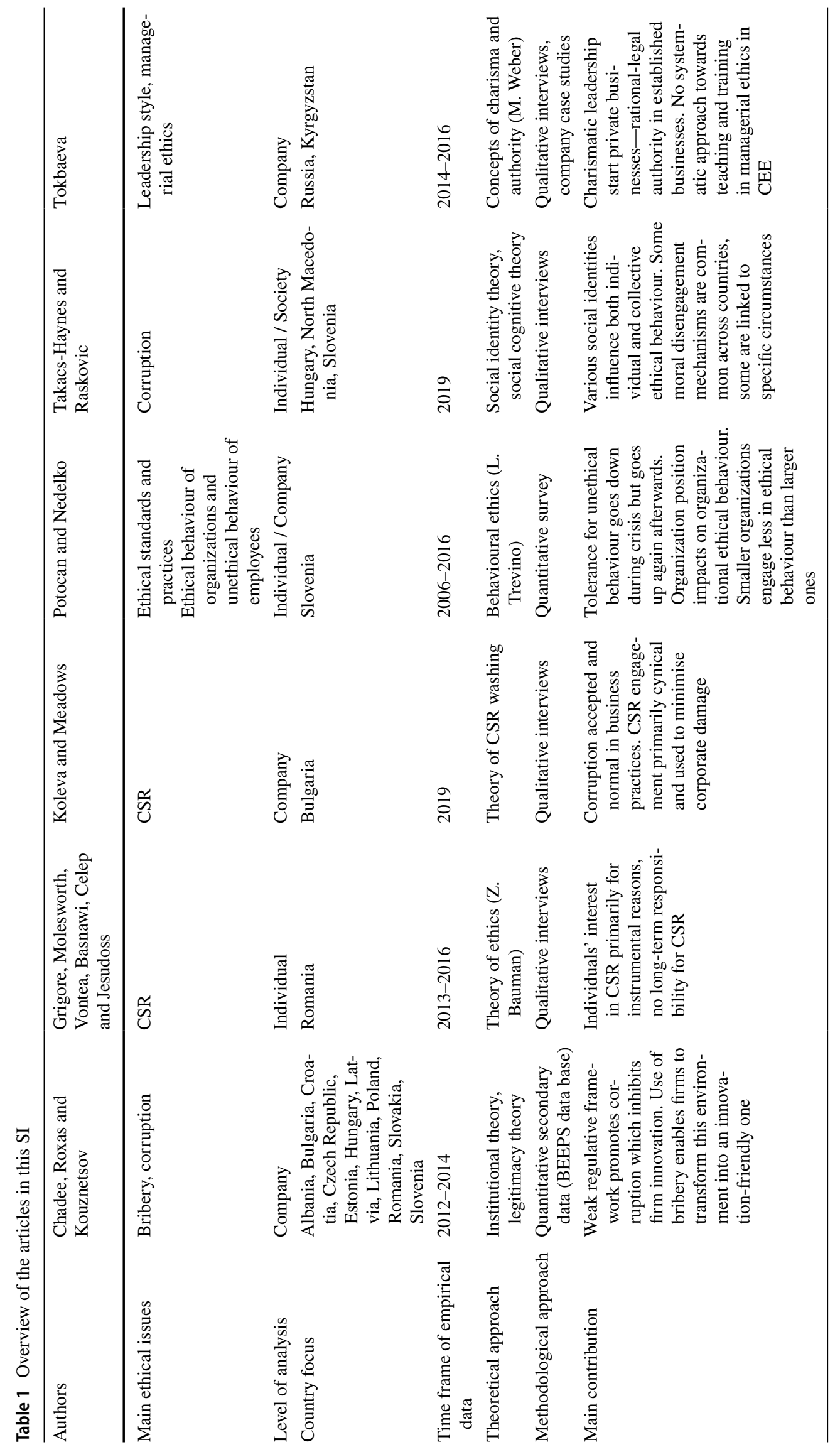


in Central and Eastern Europe (Albania, Bulgaria, Croatia, the Czech Republic, Estonia, Hungary, Latvia, Lithuania, Poland, Romania, Slovakia, Slovenia). They argue that the results show that the weak rule of law and ineffective business regulations in Central and Eastern Europe propagate the perception of corruption that inhibits firm innovation. However, interestingly, they find that the use of bribery enables firms to transform this environment of corruption into one where they can innovate. Chadee et al. (2021) develop their findings by exploring the implications of their research for policy makers and managers for differentiating between corruption and bribery, arguing that bribery acts as a glue for binding informal and formal institutions. As they note, this is a relatively under-researched area in differentiating the state of corruption and the practice of bribery.

The article by Grigore et al. (2021), explores the nature of Corporate Social Responsibility (CSR) in Romania. The authors use qualitative research methods conducting fiftythree in-depth interviews. The sample of respondents are CSR practitioners and managers in non-profit organizations who work on CSR projects and the authors study their lived experience in a post-communist society. The authors argue that researchers in the field often focus on normative and ethical claims about social progress or claims about the instrumental or strategic advantages of corporate effectiveness. In this article, their view is more upon the moral conditions of people undertaking CSR in a specific social context of a post-communist society and ethics and moral ambivalence. The authors use Zygmunt Bauman's theorisation of ethics including adiaphora and moral distancing. They also draw upon the work of Borţun's interpretation of 'Romanianness'. The authors then theorise liquid CSR as an ambivalence between adiaphoric practice (instrumental morality, careerism, and self-interest) and the moral impulse to do good, resulting in both intended (short-term promotion and competitive victimhood) and unintended consequences (a potential for corruption and collateral beneficiaries). Grigore et al. (2021) interestingly note, in their research on CSR in Romania, that individuals turn to CSR for instrumental reasons and take no responsibility for CSR in the long term. However, the authors note that they hope that Romanian people will be able to develop a broader understanding of democratic structures and citizens responsibilities, moving away from CSR projects that are in reality only a façade of progress.

The article by Koleva and Meadows (2020) also looks at Corporate Social Responsibility (CSR) and business ethics. It is a single country study, namely Bulgaria. Koleva and Meadows argue that CSR currently has a large body of theoretical literature and empirical work developed by mainly Western scholars and practitioners, but it is an underexplored topic in non-Western transition societies, particularly post-communist societies. The interest in researching
CSR and business ethics in CEE and transition economies is relatively new (Jaffe \& Tsimerman, 2005; Kooskora et al., 2005). The article is based on a qualitative approach to develop the study, using data from thirty-four executives who work in private and public sectors. In particular, Koleva and Meadows look at CSR-Washing where organizations use CSR very instrumentally and set their study against the context of the Communist period as well as developing what they call a 'Neo-Communist model' to conceptualise the links to past. They find that an unethical approach to CSR is commonplace in the Bulgarian business context as corruption is accepted and normal in business practices and taken for granted in society. The primary reason for people engaging with CSR is therefore a mainly cynical one as Bulgarian business people are sceptical about the worth of CSR as it is often deliberately used to minimise any corporate damage and to protect corporate image.

The next article by Potocan and Nedelko (this issue) looks at the significance of the 2008 economic crisis and the ethical behaviour of organizations and employees. The study is based in Slovenia and uses quantitative method of structural equation modelling to analyse answers collected from a sample of 2024 employees between 2006 and 2016. It is an article that also contributes because it has a longitudinal aspect that starts before the 2008 economic crisis allowing the authors to study changes in ethical behaviour and place them in historical context. Potocan and Nedelko also discuss the impact of the process of applying to join the European Union and its effects on ethical standards and practices in Slovenia. They note that during a crisis the tolerance for unethical behaviour goes down but after the crisis it went up again but not as much as before. Their research found that the position of respondents in the organization and organizational size significantly affected organizational ethical behaviour. Middle managers viewed the ethical duties of organizations as significantly less important compared to professionals in the study. This corresponds to the findings that managers may have a "rosier view" of ethical issues compared to other employees (Trevino et al., 2008). This could be a consequence of middle managers primary focus on employees and the organization's operational results. The authors also found that organizations with fewer than one hundred employees engage significantly less in ethical behaviour compared to organizations with more than one thousand employees thus confirming the relationship of organizational size to the business ethics of organizations (Enderle, 2004; Spence, 1999). Potocan and Nedelko note that for smaller organizations engagement in CSR beyond minimum standards is optional and costly (Williamson et al., 2006) and so concern about ethical and CSR issues is not the top priority (Steurer \& Konrad, 2009).

The article by Takacs-Haynes and Raskovic (this issue) is a comparative study that examines corruption across 
three different Central and Eastern European countries: Hungary, North Macedonia, and Slovenia. They use an unusual approach in the study: a social psychology framework which seeks to integrate social identity theory, social cognitive theory, and moral disengagement mechanisms. Adopting a qualitative approach, they conducted interviews with nine experts (Bogner \& Menz, 2009; Bogner et al., 2018) to explore how various social identities influence individual and collective action. Takacs-Haynes and Raskovic also draw upon the histories of the countries to understand the complexity and multi-layered aspects and features of the different identities, e.g., national histories, the relationship with the European Union. They argue that whilst there is a growing literature on the normalisation of corruption, less is known about the behavioural and cognitive mechanisms in ethical decision-making. In the article, they demonstrate how various social identities influence both individual and collective action in terms of ethical behaviour and corruption, creating and maintaining small-scale, grand, and systemic public and private corruption through triadic codetermination via cognition, behaviour and the environment. The authors find some moral disengagement mechanisms are common across all three countries, whilst others are linked to specific circumstances. Social identity mechanisms feed into moral disengagement, which individuals draw upon to reconcile the conflict between unethical behaviour and moral codes. Patterns of moral disengagement aggregate to the country level and explain normalisation of corruption in CEE society and organizations.

The article by Tokbaeva (this issue) deals with two media holding companies in Russia and Kyrgyzstan. It is a qualitative study primarily based on in-depth forty-three interviews conducted between 2014 and 2016. Tokbaeva uses two case studies of companies that were founded by entrepreneurs in the 1990s to set the context and explore leadership style and business ethics. The author examines post-communist ethics and leadership using Weberian concepts of charisma and legal-rational authority. Tokbaeva argues that in the 1990s and 2000s, business people (without links to elite networks) used charismatic leadership in order start private businesses and establish themselves in the market. However, once the businesses are established, the leadership style transitions to one based on rational-legal authority. Tokbaeva explores the issues of managerial ethics, e.g., career advancement and task delegation that can arise during the transition phase. The author argues that her findings confirm the earlier work of Bohatá (1997) and Rossouw (2011) that there has not been a systematic approach towards teaching and training in managerial ethics in Central and Eastern Europe and Central Asia by organizations such as the chambers of commerce.

In conclusion, the papers in this special issue make a strong contribution to understanding and theorising about the transformations in post-communist countries since the collapse of the Soviet Bloc and the ethical issues of these changes have raised for business and management in these societies. The table above shows that there are two dominant themes in the special issue submissions: Corruption and CSR. In the literature of business ethics in former communist countries, there is obviously a gap in analyses on how business ethics is managed in specific companies and what experiences these companies have had with the implementation of an ethics programme in their organizational culture. Instead, the studies explored how the companies dealt with the philosophy and "best practice" approaches of (Western) CSR. Moreover, there is also a lack of research about the quality of cooperation between government, private enterprises, and NGOs in the development of business ethics in business and society. In terms of future directions for research, it would therefore be very important to explore the role of professional and employers' associations in the development of business ethics in these countries. As discussed above, in the field of public administration and local government there have also been relatively few studies of ethics and ethical behaviour by public servants (for exceptions, see Bohatá et al., 2018; Kooskora \& Virjoka, 2015; Rybnikova \& Toleikienė, 2019; Stare \& Klun, 2016). More research focus on this would help develop more understanding of the importance of ethical behaviour and standards in public administration.

It could also be very useful to examine the role of global companies in the development of managerial and business ethics in CEE, for example, comparing the process of the implementation of ethics of one global company in different countries. Another approach that would also be beneficial would be to study the development of business ethics in small and medium-sized companies in CEE countries as those companies represent $99 \%$ of all businesses in the EU. (https://ec.europa.eu/eurostat/statistics-explained/index.php? title=Statistics_on_small_and_medium-sized_enterprises). These are just of the avenues identified for future research. Although it was not possible to include all the submitted papers, the strong interest that call for papers generated for this special issue demonstrates that there is still a substantial scholarly interest in exploring and studying ethics and ethical issues in business and management in post-communist societies.

Acknowledgements We would like to thank the reviewers who gave considerably of their time to give constructive and very helpful guidance to the authors. We would also like to thank colleagues at the University of Regensburg, led by Professor Thomas Steger, who supported and helped organise an excellent workshop (July 2019) for potential authors interested in gaining more feedback and support for developing their papers. Our deep thanks go to the editors and staff of the Journal of Business Ethics, in particular, Dr. Arno Kourula and Ms Ramya Balu for all their guidance and help during the process of organizing the special issue. We would also like to thank the anonymous reviewer for their very positive and helpful points and suggestions. 
Funding The authors have no financial or proprietary interests in any material discussed in this article.

\section{Declarations}

Conflict of interest The authors have no conflicts of interest to declare that are relevant to the content of this article.

Open Access This article is licensed under a Creative Commons Attribution 4.0 International License, which permits use, sharing, adaptation, distribution and reproduction in any medium or format, as long as you give appropriate credit to the original author(s) and the source, provide a link to the Creative Commons licence, and indicate if changes were made. The images or other third party material in this article are included in the article's Creative Commons licence, unless indicated otherwise in a credit line to the material. If material is not included in the article's Creative Commons licence and your intended use is not permitted by statutory regulation or exceeds the permitted use, you will need to obtain permission directly from the copyright holder. To view a copy of this licence, visit http://creativecommons.org/licenses/by/4.0/.

\section{References}

Amsden, A., Kochanowicz, J., \& Taylor, L. (1994). The market meets its match. Harvard University Press.

Bogner, A., \& Menz, W. (2009). The theory-generating expert interview: Epistemological interest, forms of knowledge, interaction. In A. Bogner, B. Littig, \& W. Menz (Eds.), Interviewing experts (pp. 43-80). Palgrave Macmillan.

Bogner, A., Littig, B., \& Menz, W. (2018). Generating qualitative data with experts and elites. In U. Flick (Ed.), The SAGE handbook of qualitative data collection (pp. 652-667). Sage Publications.

Bohatá, M. (1997). Business ethics in Central and Eastern Europe with special focus on the Czech Republic. Journal of Business Ethics, 16(14), 1571-1577.

Bohatá, M., Bédiová, M., Cebáková, A., Putnová, A., \& Rašticová M. (2018). Measuring social effectiveness of public institutions: A contribution to methodology. In: Dudycz, T., Osbert-Pociecha, G., \& Brycz, B. (Eds.), Efficiency in business and economics. Springer proceedings in business and economics (pp. 17-24). New York: Springer.

Brom, K., \& Orenstein, M. (1994). The privatized sector in the Czech Republic: Government and bank control in a transitional economy. Europe-Asia Studies, 46(6), 893-928.

Brown, W. S., McCabe, D., \& Primeaux, P. (2003). Business ethics in transitional economies, introduction. Journal of Business Ethics, 47(4), 295-297.

Callinicos, A. (1991). The revenge of history: Marxism and the East European Revolutions. Polity Press.

Chadee, D., Roxas, B., \& Kouznetsov, A. (2021). Corruption, bribery and innovation in CEE: Where is the link? Journal of Business Ethics. https://doi.org/10.1007/s10551-021-04925-x

Clark, E., \& Soulsby, A. (1995). Transforming former state enterprises in the Czech Republic. Organization Studies, 16(2), 215-242.

Clark, E., \& Soulsby, A. (1999). Organizational change in post-communist Europe: Management and transformation in the Czech Republic. Routledge.

Clark, E., \& Soulsby, A. (2007). Understanding top management and organizational change through demographic and processual analysis. Journal of Management Studies, 44(6), 932-954.
Enderle, G. (2004). Global competition and corporate responsibilities of small and medium-sized enterprises. Business Ethics: A European Review, 13(1), 50-63.

Eurostat. (2018). Statistics on small and medium-sized enterprises. Retrieved August 16, 2021, from https://ec.europa.eu/eurostat/ statistics-explained/index.php?title=Statistics_on_small_and_ medium-sized_enterprises

Filatotchev, I., Starkey, K., \& Wright, M. (1994). The ethical challenge of management buy-outs as a form of privatisation in Central and Eastern Europe. Journal of Business Ethics, 13(7), 523-534.

Gray, C. (1996). In search of owners: Privatization and corporate governance in transition economies. The World Bank Research Observer, 11(2), 179-197.

Grigore, G. F., Molesworth, M., Vontea, A., Basnawi, A., Celep. O., \& Jesudoss, S. (2021). Corporate social responsibility in liquid times: The case of Romania. Journal of Business Ethics. https:// doi.org/10.1007/10551-021-04926-w.

Hardy, J. (2014). Transformation and crisis in Central and Eastern Europe: A combined and uneven development perspective. Capital \& Class, 38(1), 143-155.

Haynes, M. (1992). Class and crisis-The transition in Eastern Europe. International Socialism, 54, 45-104.

Hingorani, A., Lehn, K., \& Makhija, A. K. (1997). Investor behaviour in mass privatization: The case of Czech voucher scheme. Journal of Financial Economics, 44(3), 346-396.

Hoen, H. (1996). "Shock versus gradualism" in Central Europe reconsidered. Comparative Economic Studies, 38(1), 1-20.

Holy, L. (1996). The little Czech and the great Czech nation: National identity and the post-communist social transformation. Cambridge University Press.

Hraba, J., Lorenz, F. O., \& Pechacová, Z. (2000). Czech families ten years after the velvet revolution. Journal of Contemporary Ethnography, 29(6), 643-681.

Ionescu, G. (1967). The politics of the European communist states. Weidenfeld and Nicolson.

Jaffe, E. D., \& Tsimerman, A. (2005). Business ethics in a transition economy: Will the next Russian generation be better? Journal of Business Ethics, 62(1), 87-97.

Kooskora, M., Ennulo, J., \& Virovere, A. (2005). Developing an awareness of and teaching business ethics in emerging societies-The case of Estonia. Journal of Business Ethics Education, 2(1), $29-50$.

Kooskora, M., \& Virkoja, P. (2015). Organizational ethics in the public sector organization in Estonia. In R. Pucetaite, A. Novelskaite, \& R. Pusinaite (Eds.), Organizational ethics, innovation and sustainable innovation (Scientific monograph) (pp. 441-466). Vilnius University Publishing House.

Koleva, P., \& Meadows, M. (2020). Inherited scepticism and neo-communist CSR-washing: Evidence from a post-communist society. Journal of Business Ethics. https://doi.org/10.5465/AMBPP.2020. 12861 abstract.

Kopeček, M. (2011). The rise and fall of Czech post-dissident Liberalism after 1989. East European Politics and Societies, 25(2), 244-271.

Kornai, J. (1980). Economics of shortage (Vols. A and B). North Holland Publishing.

Koubek, J., \& Brewster, C. (1995). Human resource management in turbulent times: HRM in the Czech Republic. International Journal of Human Resource Management, 6(2), 223-247.

Kozminski, A. K. (1995). From communist nomenklatura to transformational leadership: The role of management in the postcommunist enterprises. In B. Grancelli (Ed.), Social change and modernization (pp. 83-105). de Gruyter.

Lane, D. (1976). The socialist industrial state: Towards a political sociology of state socialism. Allen and Unwin. 
Lipton, D., \& Sachs, J. (1990). Privatization in Eastern Europe: The case of Poland. Brookings Papers on Economic Activity, Washington, DC: Brookings Institution.

Myant, M. (1993). Transforming socialist economies: The case of Poland and Czechoslovakia. Edward Elgar.

Myant, M., \& Drahokoupil, J. (2010). Transition economies: Political economy in Russia, Eastern Europe, and Central Asia. Wiley.

Myant, M., \& Drahokoupil, J. (2012). International integration, varieties of capitalism and resilience to crisis in transition economies. Europe-Asia Studies, 64(1), 1-33.

Newman, K. (2000). Organizational transformation during institutional upheaval. Academy of Management Review, 25(3), 602-619.

Potocan, V., \& Nedelko, Z. (this issue). The behavior of organization in economic crisis: Integration, interpretation, and research development. Journal of Business Ethics

Reed, Q. (1995). Transition, dysfunctionality and change in the Czech and Slovak Republics. Crime, Law and Social Change, 22(4), 323-337.

Remišová, A., Lašáková, A., \& Kirchmayer, Z. (2019). Influence of formal ethics program components on managerial ethical behavior. Journal of Business Ethics, 160(1), 151-166.

Rossouw, G. (2011). A global comparative analysis of the global survey of business ethics. Journal of Business Ethics, 104(1), 93-101.

Rybnikova, I., \& Toleikienė, R. (2019). Ethics management in local government of a post-socialist country: An example of decoupling? In: Tauginiené, L. (Ed.), Corporate social responsibility and business ethics in the Central and Eastern Europe, Journal of East European Management Studies (JEEMS) Special Issue (pp. 179-202), Baden-Baden: Nomos.

Sachs, J. (1996). The transition at mid-decade. AEA Papers and Proceedings, 86(2), 128-133.

Sanders, M. (2006). Privately managed privatisation in the Czech Republic: Lessons learned. Jefferson Institute.

Sicakova-Beblava, E., \& Beblavy, M. (2016). Using government manifestos to analyse the political salience and shape of anti-corruption policies in the Czech Republic and Slovakia. Policy Studies, 37(4), 295-313.

Smallbone, D., \& Welter, F. (2001). The distinctiveness of entrepreneurship in transition economies. Small Business Economics, 16(4), 249-262.

Soulsby, A., \& Clark, E. (1996). The emergence of post-communist management in the Czech Republic. Organization Studies, 17(2), 227-247.

Soulsby, A., \& Clark, E. (2007). Organization theory and the postsocialist transformation: Contributions to organizational knowledge. Special Issue: Human Relations, 60(10), 1419-1442.
Soulsby, A., Hollinshead, G., \& Steger, T. (2017). Crisis and change in industrial relations in Central and Eastern Europe. Special Issue: European Journal of Industrial Relations, 23(1), 5-15.

Spence, L. J. (1999). Does size matter? The state of the art in small business ethics. Business Ethics: A European Review, 8(3), 163-174.

Stare, J., \& Klun, M. (2016). An analysis of the ethics infrastructure and ethical climate in Slovenian Public Administration. Journal of Public Administration and Policy, 9(2), 147-163.

Steger, T., \& Lang, R. (2003). Career paths of the elite of former GDR combinates during the postsocialist transformation process. Journal of World Business, 38(3), 168-181.

Steurer, R., \& Konrad, A. (2009). Business-society relations in Central-Eastern and Western Europe: How those who lead in sustainability reporting bridge the gap in corporate (social) responsibility. Scandinavian Journal of Management, 25(1), 23-36.

Takacs-Haynes, K., \& Raskovic, M. (this issue). Living with corruption in Central and Eastern Europe: Social identity and the role of moral disengagement. Journal of Business Ethics

Tokbaeva, D. (this issue). The rise and fading away of charisma: Leadership transition and managerial ethics in the post-soviet media holdings. Journal of Business Ethics

Trevino, L. K., Weaver, G. R., \& Brown, M. E. (2008). It's lovely at the top: Hierarchical levels, identities, and perceptions of organizational ethics. Business Ethics Quarterly, 18(2), 233-252.

Večerník, J. (1999). The middle class in the Czech reforms: The interplay between policies and social stratification. Communist and Post-Communist Studies, 32(4), 397-416.

Waller, M. (1993). The end of the communist power monopoly. Manchester University Press.

Whitley, R., \& Czaban, L. (1998). Institutional transformation and enterprise change in Hungary. Organization Studies, 19(2), 259-280.

Williamson, D., Lynch-Wood, G., \& Ramsay, J. (2006). Drivers of environmental behaviour in manufacturing SMEs and the implications for CSR. Journal of Business Ethics, 67(3), 317-330.

Wolchik, S. (1991). Czechoslovakia in transition: Politics, economics and society. Pinter Publishers.

Publisher's Note Springer Nature remains neutral with regard to jurisdictional claims in published maps and institutional affiliations. 